\title{
Solanum lycopersicum Yaprak Ekstraktının Farklı İnsan Hücre Hatlarındaki Sitotoksik Potansiyeli
}

$\overline{\text { ÖZ }}$

Bitkiler geleneksel olarak çeşitli hastalıklara karşı çare olarak kullanılmaktadır. Bu çalışmada Solanum lycopersicum yapraklarının etanol ekstraktının potansiyel sitotoksik etkileri A549, HeLa, PC-3, MCF-7 ve HEK293 hücre hatlarında araştırılmıştır. Hücre canlılığının belirlenmesi için MTT deneyi kullanılmıştır. Ekstarakt ile muamele edilen A549 ve HeLa hücrelerinde apoptoz ve kaspaz-3 aktivitesi araştırılmıştır. $31.25 \mu \mathrm{g}$ $\mathrm{mL}^{-1}$ konsantrasyonda, bu ekstrakt, 72 saatte test edilen kanser hücrelerinde \% 50'den fazla sitotoksisiteye neden olmuştur. S. lycopersicum ekstraktının A549 ve HeLa hücrelerinde apoptozu indüklediği belirlenmiştir. Ayrıca, S. lycopersicum yapraklarının ekstresi aynı hücrelerde önemli kaspaz-3 aktivitesine neden olmuştur. Bu bulgular temel olarak antikanser ajanların gelişimi için S. lycopersicum yaprak ekstraktının kullanımı ile ilgili araştırmalara katkıda bulunabilir.

Anahtar Kelimeler- Sitotoksisite, Domates, İnsan Kanseri Hücre Hatları, Apoptoz.

1İletişim: mehlikaalper@mu.edu.tr (https://orcid.org/0000-0001-6193-346X)

Moleküler Biyoloji ve Genetik Bölümü, Muğla Sıtkı Koçman Üniversitesi, Muğla, Türkiye

2*Sorumlu yazar iletişim: haticegunes@mu.edu.tr (https://orcid.org/0000-0001-5191-365X)

Moleküler Biyoloji ve Biyoteknoloji Anabilimdalı, Biyoloji Bölümü, Muğla Sıtkı Koçman Üniversitesi, Muğla, Türkiye 


\title{
Cytotoxic Potential of Solanum lycopersicum Leaves Extract on Different Human Cell Lines
}

\begin{abstract}
Plants have been traditionally used as a remedy against various diseases. In this study, the potential cytotoxic effects of the ethanol extract of leaves of Solanum lycopersicum were investigated on A549, HeLa, PC-3, MCF-7 and HEK293 cell lines. MTT assay was used for determination of cell viability. Apoptosis and activity of caspase-3 in A549 and HeLa cells treated with the extract were also investigated. At a concentration of $31.25 \mu \mathrm{g}$ $\mathrm{mL}^{-1}$, this extract caused more than $50 \%$ cell death in the cancer cells that were tested for $72 \mathrm{~h}$. It was determined that the extract of $S$. lycopersicum induced apoptosis in A549 and HeLa cells. Moreover, the extract of $S$. lycopersicum leaves caused significant caspase-3 activity in same cells. These findings may basically contribute to research related with the use of the extract of leaves of S. lycopersicum for development of anticancer agents.
\end{abstract}




\section{INTRODUCTION}

Cancer is one of the important reasons of death globally. The chemotherapy used for treatment of cancer target the cells non-selectively and leads to loss of both healthy and cancer cells [1]. Structurally novel chemotypes with potent and selective biological activity may be provided from plants and other natural product extracts, and therefore, the screening of such extracts is attracted attention in drug discovery programs [2]. Plant secondary metabolites that are chemical compounds and do not have direct role in the growth of plants have some biological activities such as anti-inflammatory, anticancer and other [1]. It has been reported that the biosynthesis and accumulation of secondary metabolites, which are important in defense against pathogens and environmental stress in plant, can be affected by various genetic, ontogenic, morphogenetic and environmental factors [3]. Today, scientists investigate the various effects of different parts of many plants from different regions for finding new agents to be used in treatment of cancer and other diseases.

Solanum lycopersicum L. is a familiar vegetable called as tomato and includes important phytochemicals such as carotenoids and polyphenols which are healthy constituents and known to have efficiency in cancer prevention [4]. The fruits of tomato plants are important for the human diet [5]. Also, tomato juice has been reported to have a potential on the protection of liver health [6]. Because of their therapeutic properties, the leaves of tomato are being used in worldwide in traditional medicine. For example, the minced leaves of tomato are generally applied to the skin for a cure against insect bites [7]. Moreover, the leaves of tomato are helpful in some illness, e.g optic nerve and eye weakness [8]. To our knowledge, studies on the anticancer properties of tomato leaves are relatively limited. Therefore, this study aimed to investigate the potential cytotoxic effects of the leaves of S. lycopersicum collected from Muğla in Turkey.

\section{MATERIALS AND METHODS}

\section{A. Plant Material}

The leaves of Solanum lycopersicum (SL) were harvested in June 2015 from Muğla, Turkey. The taxonomic description was carried out and the plant material was deposited in the herbarium in Department of Biology, Mugla Sıtkı Koçman University.

\section{B. Preparation of Crude Extract}

The fresh plant leaves collected from a garden where any pesticides, herbicides or chemicals are not applied were washed with deionized water to remove the dust and dried under shade. These parts were milled to a powder by a mechanical grinder and then extracted. For the extraction, each $10 \mathrm{~g}$ of pulverized plant parts was mixed with $100 \mathrm{~mL}$ absolute ethanol (Merck, USA) for $10 \mathrm{~h}$ by a Soxhlet apparatus and then filtered using filter paper. After removing the ethanol by using a rotary evaporator at $42-43^{\circ} \mathrm{C}$, the resulting extracts were stored at $20^{\circ} \mathrm{C}$ in the dark until use. The crude extract was dissolved with $10 \%$ dimethyl sulfoxide (DMSO) (Applichem, USA) to obtain stock solutions. Serial dilutions were prepared in the growth medium for use in the subsequent experiments. DMSO in a concentration not exceeding $1 \%$ was used in cells tested in the MTT assay.

\section{Cell Culture Conditions and Cytotoxicity Assay}

A549 (lung adenocarcinoma), HeLa (cervix adenocarcinoma), PC-3 (prostate adenocarcinoma), MCF-7 (breast adenocarcinoma) and HEK293 (embryonic kidney) human cell lines that were used in this study were obtained from ATCC and maintained in an RPMI 1640 medium (Biochrom, Germany) with stable L-glutamine (Biochrom, Germany) containing 10\% heat-inactivated fetal bovine serum (FBS) (Biochrom, Germany) supplemented with 100 units $\mathrm{mL}^{-1}$ of penicillin and $100 \mu \mathrm{g} \mathrm{mL}-1$ of streptomycin (Biochrom, Germany)and incubated at $37^{\circ} \mathrm{C}$ in a humidified atmosphere with $5 \% \mathrm{CO}_{2}$ and $95 \%$ air, and checked with an inverted microscope every day for their growth and morphologies. The potential cytotoxic effects of the extract against the cell lines were detected by an MTT assay [9]. The cell lines were plated separately at a density of $4 \times 10^{3}$ cells/well into 96-well plates (Greiner, Germany) as triplicates. After for $24 \mathrm{~h}$ incubation at $37^{\circ} \mathrm{C}$, the cell lines were exposed to extract at six different concentrations $\left(31.25-1000 \mu \mathrm{g} \mathrm{mL}^{-1}\right)$ for $72 \mathrm{~h}$. Later, the culture medium with the extract in the wells was discarded. After addition $100 \mu \mathrm{L}$ of fresh growth medium to each well, $10 \mu \mathrm{L}$ of the MTT (3-(4,5-Dimethyl-2-thiazolyl)-2,5-diphenyl-2H-tetrazolium Bromide) (Applichem, USA) solution (5 
$\mathrm{mg} \mathrm{mL} \mathrm{L}^{-1}$ in a phosphate buffer solution) was added to each well and the microplates were incubated for another 4 $\mathrm{h}$ at $37^{\circ} \mathrm{C}$. At the end of incubation time, the media including MTT were removed from each well and $100 \mu \mathrm{L}$ of DMSO (Applichem, USA) was added into each well for dissolution the formazan crystals produced by living cells. Untreated cells were used as control groups. A microplate reader (Thermo Scientific, Multiskan FC, USA) was used to record the absorbance (Abs) at $540 \mathrm{~nm}$ for each well. The cell viability was calculated according to the following formula:

Cell viability $\%=($ Mean Abs of treated cells/Mean Abs of untreated cells $) \times 100$

\section{Annexin-V/PI Staining Assay}

Annexin V-FITC/propidium iodide (PI) staining was performed to evaluate the percentage of apoptotic cells in treated cells via an annexin V-FITC apoptosis detection kit (eBioscience, BMSF500FI/100).The A549 and HeLa cells $\left(5 \times 10^{5}\right.$ cells/well) were treated with 250 and $500 \mu \mathrm{g} \mathrm{mL} \mathrm{L}^{-1}$ of the extract for $24 \mathrm{~h}$ in 6 -well plates. The cells treated with DMSO (below 1\%) served as control cells. After incubation time, the cells were trypsinized. The harvested cells were washed with PBS. After centrifugation at $120 \mathrm{xg}$ for $5 \mathrm{~min}$ at $4^{\circ} \mathrm{C}$, the cell pellets were resuspended in $190 \mu \mathrm{L}$ of binding buffer. Then, $5 \mu \mathrm{L}$ of Annexin V-FITC were added to each cell suspension, and the cells were incubated in dark at room temperature for $10 \mathrm{~min}$. After centrifugation, the cell pellets were again dissolved in $190 \mu \mathrm{L}$ of binding buffer, and they were then stained by adding $10 \mu \mathrm{L}$ of PI (20 $\left.\mu \mathrm{g} \mathrm{mL}^{-1}\right)$ at room temperature in the dark. After staining, total 10,000 cells from each sample were analyzed per measurement by flow cytometry (BD FACSCanto A, BD Biosciences) using the BD FACSDiva software v6.13.

\section{E. Caspase-3 Activity Assay}

Activity of caspase-3 was investigated by using a colorimetric assay kit (Abcam, Cambridge, UK) according to the manufacturer's protocol. A549 or HeLa cells were cultured in 6-well plates at a density of $2 \times 10^{6}$ cells/well. After $24 \mathrm{~h}$ incubation, the cells were exposed to $500 \mu \mathrm{g} \mathrm{mL}-1$ of extract for $36 \mathrm{~h}$. Later, $50 \mu \mathrm{L}$ of cell lysis buffer were added to each cell pellets. This mixture was incubated for $10 \mathrm{~min}$ on ice. After centrifugation at $10,000 \mathrm{x} g$ for $1 \mathrm{~min}$, the protein concentration was detected by the Bradford assay [10]. Then, each sample with an amount of $200 \mu \mathrm{g}$ of protein was incubated with $50 \mu \mathrm{L}$ of $2 \mathrm{X}$ reaction buffer (containing $10 \mathrm{mM}$ of DTT) and $5 \mu \mathrm{L}$ of the colorimetric substrate (4 mM DEVD-p-NA) for caspase-3, during $2 \mathrm{~h}$ at $37^{\circ} \mathrm{C}$. The absorbance at 405 $\mathrm{nm}$ was recorded. Control cells were untreated cells. Caspase-3 activity was expressed as the fold-increase in caspase-3 activity via comparison of the absorbance of treated cells with that of control cells.

\section{F. Statistical Analysis}

The results are expressed as mean \pm standard error (SE) and were analyzed using GraphPad Prism 7.0 (GraphPad Software, Inc., San Diego, CA).

\section{RESULTS AND DISCUSSION}

\section{A. Cytotoxic Effects of the Extracts}

The increasing concentrations $(31.25-1000 \mu \mathrm{g} \mathrm{mL}-1)$ of SL ethanolic leaves (SLEL) extract were tested on the different cell lines for determination of potential cytotoxicity by MTT assay. As shown in Figure 1, all concentrations of the SLEL extract were observed to cause more than $50 \%$ cell death in all cancer cell lines tested. However, this extract at $125 \mu \mathrm{g} \mathrm{mL} \mathrm{m}^{-1}$ induced about $50 \%$ cytotoxicity on the HEK293 cell line. Moreover, this extract at $31.25 \mu \mathrm{g} \mathrm{mL} \mathrm{m}^{-1}$ concentration did not show significant cytotoxicity against the HEK293 cell line. These results suggested that the SLEL extract possessed potent cytotoxic effects against cancer cell lines rather than non cancerous HEK293 cell lines. 


\begin{tabular}{|c|c|c|}
\hline & $\begin{array}{l}\text { BŞEÜ Fen Bilimleri Dergisi } \\
7(2), 544-552,2020\end{array}$ & $\begin{array}{r}\text { BSEU Journal of Science } \\
\text { DOI: } 10.35193 / \text { bseufbd.682245 }\end{array}$ \\
\hline & & 88-7575 (http://dergipark.gov.tr/bseufbd) \\
\hline
\end{tabular}
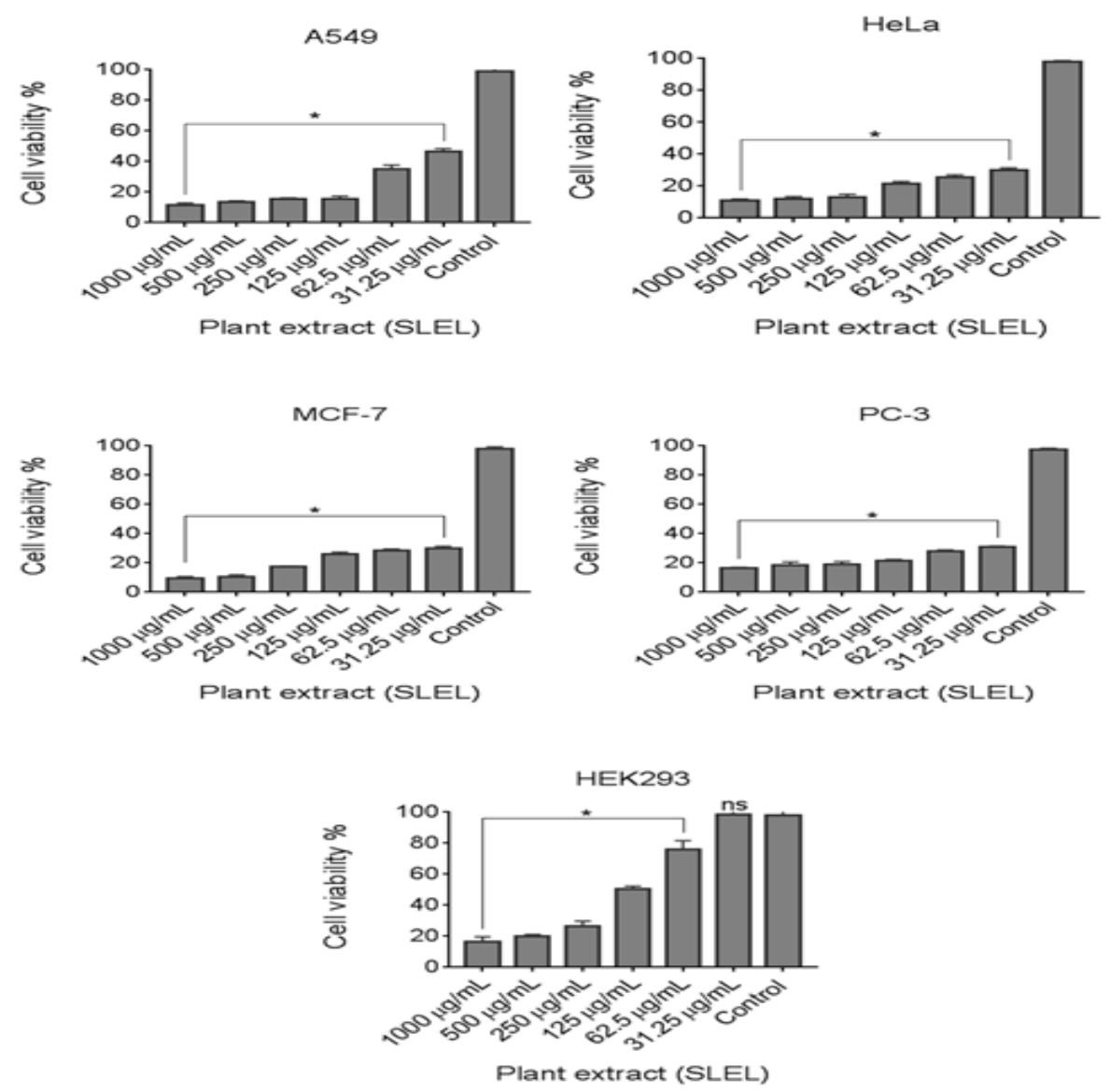

Figure 1. Cytotoxic effects of SLEL extract at different concentrations. The values obtained from three independent experiments for $72 \mathrm{~h}$ were presented as mean \pm SE. ${ }^{*} P<0.05$ and ns: non-significant $(P>0.05)$ compared to control cells (one-way ANOVA and Tukey's multiple comparison test)

Plants have significant potential for the prevention and treatment of cancer due to the secondary compounds they naturally produce, and these compounds are being studied for anticancer activities that lead to the development of new drugs. [11], so it is important to investigate the anticancer properties of plants gathered from different places. In a previous study, Chik et al. [8], using different solvent for extraction unlike the current study, investigated the cytotoxicity effect of methanol extract of leaves of tomato (Lycopersicum esculentum) on MCF-7 breast cancer cell lines and Vero cells, and demonstrated that purified sample caused notable effects against MCF-7 with $\mathrm{IC}_{50}$ values of $5.85 \mu \mathrm{g} \mathrm{mL}-1$, while Taxol had the $\mathrm{IC}_{50}$ value of $0.039 \mu \mathrm{g} \mathrm{mL}^{-1}$, and it was evaluated to be harmless on normal mammalian Vero cells $\left(\mathrm{IC}_{50}\right.$ values of $765.6 \mu \mathrm{g} \mathrm{mL}^{-1}$ ) while Taxol provided the $\mathrm{IC}_{50}$ value of $0.045 \mu \mathrm{g} \mathrm{mL} \mathrm{L}^{-1}$.The researchers also declared that the extract of tomato leaves contains purified active fractions that have anticancer features. Additionally, Saturnino et al. [7] tested the extracts of Black Tomato leaves (var. Paul Robenson) on HEK-293, MCF-7 and C6 (rat glioma) cells for determination of their cytotoxicity. They reported that hydrophilic and chloroform extracts exhibited a comparable cytotoxic activity with cisplatin on C6, whereas the total extract did not cause a significant activity on this cell line. These researchers also stated that any significant activity was not applied by all three extracts on MCF-7 and HEK-293 cell lines. Mbaveng et al. [12], using different extract and different cells unlike the present study, studied 21 methanol extracts from 18 Cameroonian medicinal plants against leukemia CCRF-CEM cells and further tested the best extracts on a panel of human cancer cell lines, including various multi-drug-resistant (MDR) phenotypes. They showed that Lycopersicon esculentum leaves had $\mathrm{IC}_{50}$ values from $9.64 \mu \mathrm{g} / \mathrm{mL}$ (against breast adenocarcinoma MDA-MB-231 cells) to $57.74 \mu \mathrm{g} / \mathrm{mL}$ (against HepG2 cells). All these data support that the site where the plants are collected and the solvent selected for extraction may alter cytotoxic activity according to the 
cell type that is used. In addition, the acute toxicity and subacute oral toxicity of methanolic extract of Lycopersicon esculentum leaves was explored through oral administration. A single dose of extract of leaves of L. esculentum has been shown to be relatively non-toxic at a dose of $5000 \mathrm{mg} / \mathrm{kg} \mathrm{b.w..} \mathrm{Also,} \mathrm{it} \mathrm{has} \mathrm{been} \mathrm{reported}$ that long-term use of L. esculentum at orally low doses (250 and $500 \mathrm{mg} / \mathrm{kg}$ ) should be encouraged and however highest dose $(1000 \mathrm{mg} / \mathrm{kg})$ should be avoided [13].The results support that tomato leaves may be a promising agent for cancer treatment.

\section{B. Determination of Apoptotic Cells}

Since the extract at 250 and $500 \mu \mathrm{g} \mathrm{mL}-1$ caused more than $85 \%$ cytotoxicity on A549 and HeLa cells, annexin V-FITC/PI staining was carried out to see if apoptosis was induced in these cells after treatment with SLEL extract for $24 \mathrm{~h}$. Flow cytometry was performed to demonstrate the apoptosis rate (quadrants Q4 and Q2) of the cells. The results indicated that the SLEL extract at $500 \mu \mathrm{g} \mathrm{mL}^{-1}$ increased the percentage of the apoptotic cells by $82.5 \%$ in the A549 cells and $63.8 \%$ in the HeLa cells in comparison to the control cells. Importantly, the increase of percentage of apoptosis in the A549 cells treated with $250 \mu \mathrm{g} \mathrm{mL} \mathrm{m}^{-1}$ of SLEL extract $(82.2 \%)$ was found to be similar to cells treated with $500 \mu \mathrm{g} \mathrm{mL}^{-1}$ of the extract. However, the $250 \mu \mathrm{g} \mathrm{mL}^{-1}$ SLEL extract increased the percentage of apoptotic HeLa cells by $29 \%$ in comparison to the control groups. In addition, unlike HeLa cells, apoptosis in A549 cells was predominant in the early apoptotic phase (quadrant Q4).These results suggest that the SLEL extract significantly induced the apoptosis in both cell lines, especially in A549 (Figure 2).
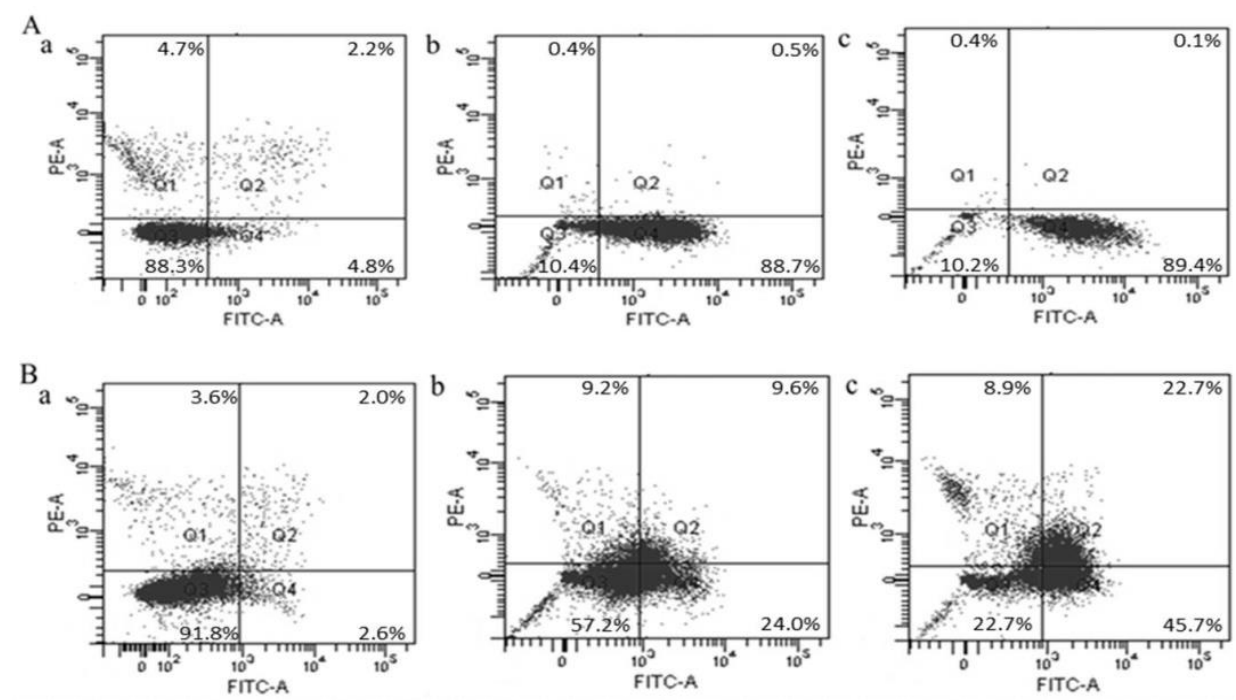

Figure 2. SLEL-induced apoptosis on A549 and HeLa cells. A549 (A) and HeLa (B) cells were treated with 250 (b) and $500 \mu \mathrm{g} \mathrm{mL} \mathrm{m}^{-1}$ (c) SLEL extract for $24 \mathrm{~h}$. The cells treated with DMSO served as control (a). Effects of SLEL extract on apoptosis of the cells were assessed by flow cytometry. Cells were distributed into four quadrants: Q3: viable cells, Q4: early apoptotic cells, Q2: late apoptotic cells and Q1: necrotic cells.

Apoptosis known as programmed cell death is a natural mechanism in the cells. Apoptosis, which is important in providing homeostasis, also plays a crucial act in the development of mammals. This process, which takes part in eliminating unnecessary or unwanted cells, is an extremely controlled. The apoptotic pathways, which are intracellular or extracellular, provoke death of cells by inducing caspases. Evasion of apoptosis is one of the hallmarks of cancer and the one of essential duty of apoptosis is the cancer prevention. The controlling or stopping the growth of cancer cells is among the treatment ways of cancer. Targeting apoptosis is a highly potent method for all types of cancer because evasion of apoptosis is not specific to types of cancer [14]. The pure bioactive compounds and total extracts obtained from different tomatoes or tomato products were stated to induce apoptosis in previous studies [15-18]. In addition, the extract of Lycopersicon esculentum leaves has been 
reported to induce mostly necrosis in CCRF-CEM leukemia cells after $24 \mathrm{~h}$ of treatment at $2 \mathrm{x} \mathrm{IC}_{50}$, which the $\mathrm{IC}_{50}$ value was stated as $17.94 \mu \mathrm{g} / \mathrm{ml}[12]$. This present study also suggested that the ethanolic extract obtained from tomato leaves was able to be a credible source for development of new agents targeting apoptosis in treatment of cancer.

\section{Determination of Caspase-3 Activity}

The effects of the SLEL extract on caspase-3 activation in A549 and HeLa cells were investigated because it is known that caspase-3 has a critical role in execution of apoptosis [19]. The extract at the concentration of $500 \mu \mathrm{g} \mathrm{mL}^{-1}$ was found to cause about an 8.5- and 4.5-fold increase in the caspase-3 activity of the A549 cells and HeLa cells, respectively in comparison to the control groups (Figure 3). These findings were appropriate with the results obtained by the flow cytometric data. The result suggested that the ethanolic tomato leaves extract may induce apoptosis in both cells. It has been stated that different cell lines or tissues may react differently to the same conditions and the same agent may stimulate apoptosis in one cell line but not in another. In addition, with the identical that induces apoptosis, the duration of the apoptosis process may vary in different cells [20] so; apoptosis rate in cells tested in the present study is likely to be different. Also, Mbaveng et al. [12] demonstrated that the extract from Lycopersicon esculentum leaves induced apoptosis mediated by caspases activation and increase ROS production. Considering all these results, it can be said that tomato leaves have apoptotic potential.

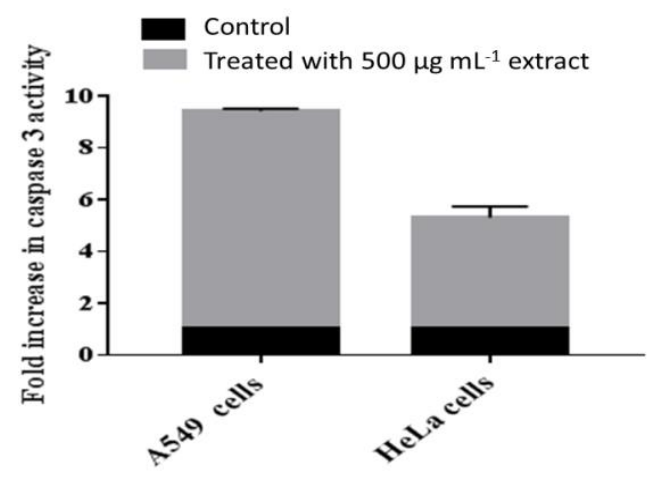

Figure 3. Caspase 3 activity in A549 and HeLa cells.A549 and HeLacells were treated with $500 \mu \mathrm{g} \mathrm{mL}^{-1} \mathrm{SLEL}_{\mathrm{extract}}$ for $36 \mathrm{~h}$. Untreated cells served as control. The caspase- 3 activities in control cells were taken as 1-fold and other activity in the treated cells were given as relative changes. The results were means $( \pm \mathrm{SE})$ of three independent experiments.

\section{CONCLUSION}

In conclusion, crude ethanolic leaves extract of SL at $31.25 \mu \mathrm{gmL}^{-1}$ displayed higher cytotoxicity against all cancer cell lines tested when it was compared to the HEK293 cell line. In addition, the extract at 500 $\mu \mathrm{g} \mathrm{mL} \mathrm{mL}^{-1}$ exhibited an important apoptotic effect and caspase-3 activity in A549 and HeLa cell lines compared with the control groups. It is known that the fruits of tomato, which is an important foodstuff, have protective and therapeutic properties against diseases. Based on the results obtained from this study, it may be suggested that tomato leaves may be also be a potential source for new chemotherapeutic agents against cancer.

\section{REFERENCES}

[1] Kooti, W., Servatyari, K., Behzadifar, M., Asadi-Samani, M., Sadeghi, F., Nouri, B., \& Zare Marzouni, H. (2017). Effective Medicinal Plant in Cancer Treatment, Part 2: Review Study. Journal of evidence-based complementary \& alternative medicine, 22(4), 982-995

[2] Kinghorn, D. (2000). Plant secondary metabolites as potential anticancer agents and cancer chemopreventives. Molecules, 5, 285-288. 
[3] Yang, L., Wen, K. S., Ruan, X., Zhao, Y. X., Wei, F., \& Wang, Q. (2018). Response of Plant Secondary Metabolites to Environmental Factors. Molecules (Basel, Switzerland), 23(4), 762.

[4] Martí, R., Roselló, S., \& Cebolla-Cornejo, J. (2016). Tomato as a source of carotenoids and polyphenols targeted to cancer prevention. Cancers (Basel), 8(6), 58.

[5] Gerszberg, A., Hnatuszko-Konka, K., Kowalczyk, T., \& Kononowicz, A. K. (2015). Tomato (Solanum lycopersicum L.) in the service of biotechnology. Plant Cell, Tissue Organ Culture, 120(3), 881-902.

[6] Navarro-González, I., García-Alonso, J., \& Periago, M. J. (2018). Bioactive compounds of tomato: Cancer chemopreventive effects and influence on the transcriptome in hepatocytes. Journal of Functional Foods, 42, 271-280.

[7] Saturnino, C., Spagnuolo, A., Palladino, C., Popolo, A., Tommonaro, G., De Prisco, R., \& Pinto, A. (2013). Antiproliferative activity of "Lycopersicon esculentum" leaves (var. Paul Robenson): Preliminary study. Food and Nutrition Sciences, 4, 632-635.

[8] Chik, W.D.W., Amid, A., \& Jamal, P. (2010). Purification and cytotoxicity assay of tomato (Lycopersicon esculen tum) leaves methanol extract as potential anticancer agent. Journal of Applied Sciences, 10(24), 3283-3288.

[9] Mosmann, T. (1983). Rapid colorimetric assay for cellular growth and survival: Application to proliferation and cytotoxicity assays. Journal of lmmunological Methods, 65, 55-63.

[10] Bradford, M.M. (1976). A rapid and sensitive method for the quantitation of microgram quantities of protein utilizing the principle of protein-dye binding. Analytıcal Biochemistry, 72, 248-254

[11] Greenwell, M., \& Rahman, P.K.S.M. (2015). Medicinal Plants: Their use in anticancer treatment. International Journal of Pharmaceutical Sciences and Research, 6(10), 4103-4112.

[12] Mbaveng, A. T., Manekeng, H. T., Nguenang, G. S., Dzotam, J. K., Kuete, V., \& Efferth, T. (2018). Cytotoxicity of 18 Cameroonian medicinal plants against drug sensitive and multi-factorial drug resistant cancer cells. Journal of Ethnopharmacology, 222, 21-33.

[13] Nguenang, G. S., Ntyam, A., \& Kuete, V. (2020). Acute and Subacute Toxicity Profiles of the Methanol Extract of Lycopersicon esculentum L. Leaves (Tomato), a Botanical with Promising In Vitro Anticancer Potential. Evidence-Based Complementary and Alternative Medicine : eCAM, 2020, 8935897.

[14] Pfeffer, C. M., \& Singh, A. T. K. (2018). Apoptosis: A target for anticancer therapy. International Journal of Molecular Sciences, 19(2), 448.

[15] Hwang, E.-S., \& Bowen, P. E. (2005). Effects of tomato paste extracts on cell proliferation, cell-cycle arrest and apoptosisin LNCaP human prostate cancer cells. BioFactors, 23, 75-84.

[16] Holzapfel, N. P., Holzapfel, B. M., Champ, S., Feldthusen, J., Clements, J., \& Hutmacher, D. W. (2013). The potential role of lycopene for the prevention and therapy of prostate cancer: From molecular mechanisms to clinical evidence. International Journal of Molecular Sciences, 14(7), 14620-14646.

[17] Soares, N.C.P., Machado, C.L., Trindade, B.B., Lima, I.C.C., Gimba, E.R.P., Teodoro, A.J., Takiya, C., \& Borojevic, R. (2017). Lycopene extracts from different tomato-based food products induce apoptosis in cultured human primary prostate cancer cells and regulate TP53, Bax and Bcl-2 transcript expression. Asian Pacific Journal of Cancer Prevention, 18(2), 339-345.

[18] Barone, D., Cito, L., Tommonaro, G., Abate, A.A., Penon, D., De Prisco, R., Penon, A., Forte, I.M., Benedetti, E., Cimini, A., Indovina, P., Nicolaus, B., Pentimalli, F., \& Giordano, A. 2018. 


\begin{tabular}{|c|c|c|}
\hline & $\begin{array}{l}\text { BŞEÜ Fen Bilimleri Dergisi } \\
7(2), 544-552,2020\end{array}$ & $\begin{array}{r}\text { BSEU Journal of Science } \\
\text { DOI: } 10.35193 / \text { bseufbd.682245 }\end{array}$ \\
\hline 0 & & 58-7575 (http://dergipark.gov.tr/bseufbd) \\
\hline
\end{tabular}

Antitumoral potential, antioxidant activity and carotenoid content of two Southern Italy tomato cultivars extracts: San Marzano and Corbarino. Journal of Cellular Physiology, 233, 1266-1277.

[19] Porter, A.G., \& Jänicke, R.U. (1999). Emerging roles of caspase-3 in apoptosis. Cell Death \& Differentiation, 6, 99-104.

[20] Sundquist T., Moravec, R. , Niles, A., O'Brien, M., Riss T., Promega Corporation (2006). Timing your apoptosis assays. Cell Notes 16, 18-21. 